\title{
An analysis of the impact of the top management's qualifications and competence on the competitive position of Polish enterprises
}

\author{
Jolanta Lubomska-Kalisz \\ University of Szczecin \\ Poland \\ j.lubomska-kalisz@wp.pl
}

\begin{abstract}
The article provides a theoretical approach to the staff's job qualifications and competence, and the competitive position of enterprises. Based on empirical research, an analysis was performed of the correlation between the competitive position of enterprises and the top management's qualifications, and between the competitive position and the top managers' competence in small and medium enterprises (SMEs). The research results show how the competitive position of enterprises depends on the level of the top managers' educational background and on the level of particular types of their competence.
\end{abstract}

Received: June, 2014 1st Revision: September, 2014

Accepted:

October, 2014

DOI:

$10.14254 / 2071-$ $8330.2014 / 7-2 / 10$

Keywords: competitiveness of enterprises, competitive position of enterprises, top management's qualifications and competence, small and medium enterprises (SMEs).

JEL Classification: L 26

\section{INTRODUCTION}

Under the circumstances of the contemporary global and highly-competitive economy, the competitiveness of enterprises is a foundation for their success and development. Therefore, questions arise that concern the Polish small and medium enterprise (SME) sector. On the one hand, these are questions about the present level of these enterprises' competitiveness, as their prospects for development can be forecast while assessing how competitive they are. On the other hand, these are also questions about the factors affecting their competitiveness, or their competitive position. An ability to define the individual elements of the competitive potential, as well as their influence on the ultimate competitiveness, can enable one to strengthen deliberately those elements that play the key role under the given conditions. By doing this, the competitiveness of enterprises can be improved, which can result in market success and growth. Within the framework of the knowledge economy (KE), among the competitive potential factors particular significance is attributed to those related to the staff's (above all the top management's) qualifications and competence.

Given the above, it became an important scientific problem and the subject of this paper to: firstly analyze the influence of the top management's qualifications on the competitive position of Polish small and medium enterprises (SMEs), and secondly - to analyze the influence of the top management's competence on their competitive position. As the main research method, quantitative research was carried out in small and medium enterprises using questionnaire-based paper and pencil interviews. 


\section{QUALIFICATIONS, COMPETENCE AND THE COMPETITIVE POSITION OF THE ENTERPRISE FROM THE THEORETICAL POINT OF VIEW}

Qualifications include all types of knowledge and skills, as well as such characteristics that are important for the completion of professional tasks, or those that describe how people function within communities or their work environment not limited merely to the conditions dictated by technologies and equipment. In this sense, the meaning of qualifications is close to that of competence, and a standardized set of professional qualifications can be considered as equivalent to the competency profile required at a given post (www. mpips.gov.pl).

Qualifications, or in other words "the knowledge of the subject", mean a verifiable, measurable and assessable high level of expertise in the subject. A qualified employee is one that is thoroughly educated, has a comprehensive knowledge and practical experience in the given area, and is licensed to do the job. Such qualifications can be of a formal nature and take the form of school diplomas, vocational diplomas, certificates, licenses, seniority, etc. Qualifications can be measured (e.g. by the number of years spent at a given post), compared to others in the same group and assessed (www.biurokarier.umk.pl).

Qualifications defined as the acquired skills and knowledge are still important, although at present they are sought together with competence, i.e. individual abilities, and psychosocial and behavioral predispositions. As the vertical and hierarchical enterprise organization is being more and more abandoned in favor of flat organizations following the "networking" model, more and more significance is being attributed to social competencies, referred to as soft ones, which can be defined as interpersonal skills: an ability to cooperate (to work in teams), communicate, persuade and mediate, build an authority, be flexible, adapt to changes and be ready to take risks. As human resource advisors confirm: "You get a job in 70\% thanks to your professional knowledge and in 30\% thanks to your social skills. However, you lose it in $70 \%$ due to a lack of social skills and in 30\% due to a lack of formal qualifications." Currently, a job is now not only looked at from the angle of qualifications, or skills required to do it, but first of all from the angle of competence - how the given job fits the company's internal network of relations, what personal and behavioral characteristics are required by such relations. In the saying "the right person in the right place", the emphasis is now put on the person (www.biurokarier.umk.pl).

The concept of employee competence first appeared in the works of D. McClelland (McClelland, 1973) and R. Boyatzis (Boyatzis, 1982) of the United States and, which is less known, in the works of J. Raven (Raven, 1984) of the United Kingdom. These authors were looking for a method to differentiate employees according to the results of their work (Sienkiewicz, Gruza, 2009). R. Boyatzis described competence as "the potential, existing within the human, leading to such a behavior that helps to satisfy the requirements at a given post" (Boyatzis, 1982). Nevertheless, these terms were later expanded gradually.

Such employee characteristics were seen to form competence as: knowledge, skills, talents, personality traits, values, beliefs, motivation and the image of one's own person. In enterprise practice, competences are seen as employee characteristics represented by knowledge, skills and abilities (KSA), and as personality traits required for one's job to be performed properly. At the same time, an emphasis is put on the causality between the employee's properties and the high or higher-than-average results of their work, which are of a measurable nature (Spencer L.M., Spencer S.M, 1993) (Pocztowski, 2001) (Woodruffe, 2003). Most of the competence traits (properties) are grouped in the four main categories of: knowledge, skills, predispositions and attitudes (Sienkiewicz, Gruza, 2009).

In the Polish Qualifications Framework (www.kwalifikacje.praca.gov.pl), compliant with the European Qualifications Framework, the definitions concordant with the Recommendation of the European Parliament and of the Council of 23 April 2008 on the establishment of the European Qualifications Framework 
for lifelong learning, 'competence' means the proven ability to use knowledge, skills and personal, social and/ or methodological abilities, in work or study situations and in professional and personal development. In the context of the European Qualifications Framework, competence is described in terms of responsibility and autonomy (Sienkiewicz, Gruza, 2009).

An attempt at developing a comprehensive competence model was undertaken by, among others, Delamare Le Deist and J. Winterton (Delamare Le Deist, Winterton, 2005), who at the same time introduced a division into cognitive, functional, social and meta-competences.

Cognitive competence is related to an ability to learn and memorize. This competence is larger when people are not led by stereotypes or prejudices. Functional competence is connected with an efficient functioning at one's post. Social competence refers to the specifics of establishing and maintaining relationships with other people. Meta-competence is concerned with, on the one hand, an ability to learn and have reflections, and on the other hand, an ability to cope with uncertainty (Delamare Le Deist, Winterton, 2005).

For the purposes of this paper, competence is understood as professional qualifications gained not only through official or course-based education, but also through experience. Apart from that, competence also comprises knowledge and skills not directly related to the job specialization, and the employee's predispositions and attitudes (PARP Report 2010).

Employee competence is here described using the competence model developed by G. Filipowicz, which was also used for my empirical research (Filipowicz, 2004). In this work, competences are divided into 2 categories:

1. base competences - a group of competences related to the quality of our functioning and our contacts with others:

a) cognitive (solving problems, flexible thinking, readiness to learn),

b) social (relations with superiors and peers, communicativeness, negotiation skills, ability to work in teams, manners),

c) personal (resistance to stress, perseverance, diligence, work organization, self-confidence),

2. executive competences - a group of competences related to the actions performed within the given profession and/or function, or referring to the specific area of the person's activity and the functioning of the enterprise:

a) business (knowledge of the business, knowledge of the industry, diagnosing the customer's needs, sales techniques),

b) enterprise-related (identifying oneself with the enterprise, professional knowledge, ethics and values, openness to changes),

c) managerial (delegating, organizing, motivating, leadership, process and project management, strategic thinking).

Competitive (competing) strategy is widely understood as the manner in which the enterprise behaves towards its competitors. According to M.E. Porter, competitive strategy is „a combination of goals for which the business is striving and the policies through which it is trying to get there" (Porter, $2006 \mathrm{~b}$ ). He finds that "the competitive strategy of a firm is to find a favorable competitive position within its industry, which is the most important area from the point of view of competition". (Porter, 2006 a).

The elaborate concept of enterprise competitiveness by M.J. Stankiewicz treats competitiveness as a system (aggregate) consisting of four elements (subsystems): competitive potential, competitive advantage, competition instruments and competitive position (Stankiewicz, 2005). In this model, competitive advantage (always of a relative nature) can be understood as a configuration of competitive potential components allowing the enterprise to generate effective competition instruments, i.e. the tools and methods to win 
customers. The last of the competition elements is competitive position, i.e. the place on the economic and non-economic benefits scale that the enterprise delivers to its stakeholders, as compared to the places occupied by its competitors.

In this paper, an enterprise competitiveness model based on M.J. Stankiewicz's concept was used.

Among the views proposed in literature concerning the nature of competitive position, three approaches are generally distinguished (Stankiewicz, 2005):

- the first group of views treats competitive position as a manifestation of the enterprise's competitive possibilities that stem from its strengths and that constitute its critical success factors. Competitive position is treated as the source of the advantage achieved. This view is held by groups of French authors known as STRATEGOR, American authors - A.C. Hax and N.S. Majluf, as well as Polish authors - G. Gierszewska and M. Romanowska (see Strategor, 2001; Hax, Majluf, 1990; Gorynia, 2000; Gorynia, Łaźniewska 2010; Gierszewska, Romanowska, 2009);

- the second group of views see competitive potential as a measure of the competitive advantage achieved, thus as a result of competition, and not as the source of strengths used while competing. This view is held by such authors, among others, as J. Kay, G.S. Day, or B. Godziszewski, whose outlook is close to this view (Kay, 1996; Day, 1997; Godziszewski, 2001);

- the third group of views interprets competitive position as the source, manifestation and measurement of competition simultaneously. This view is represented by Scottish authors James and Jennifer Taggart, who base their opinions on the concepts developed by P. Buckley, C. Pass, K. Prescott and the Polish author Z. Pierścionek (Taggart; Buckley, Pass, Prescott, 1988; Pierścionek, 2007).

Competitive advantage stems from competitive potential, which is the entirety of the enterprise's tangible and intangible resources required for the entity to function in the competitive arena (Stankiewicz, 2005). Among these resources, their variants referred to as competences and/or skills are distinguished as separate from each other. This distinction was most probably introduced to literature by E.T. Penrose (Penrose, 1959). R. Boyatzis claims that the popular understanding of competence brings it down to the underlying characteristic of a person, such as their motive, trait, aspect of their self-image, social role, or a body of knowledge which he/she uses, etc. (Boyatzis, 1982).

J. Low, P.C. Kalafut and many other authors believe nowadays that such intangible resources as leadership, intellectual capital, human capital, workplace culture, innovation, adaptability, strategy execution, communication, brand equity, reputation, alliances and networks, technologies and processes are becoming more and more significant in creating competitive advantage (Low, Kalafut, 2002; Flak, Głód, 2009). P. Lyons shows the influence of managerial preparation (knowledge, practical skills and learning skills), interpersonal skills (mental and intellectual preparation) and skills in shaping interpersonal relations on the effects of the manager's work, and the consequent results of their organization (Lyons, 2007; Flak, Głód, 2009).

\section{TOP MANAGEMENT'S QUALIFICATIONS AND THE ENTERPRISES' COMPETITIVE POSITION}

The main method used in this paper for pursuing the research objectives was empirical research in the form of quantitative research. Empirical data presented herein were discussed on the basis of "The educational background of employees and the enterprises' competitive position” Research Report, which research was conducted by WYG group's PSDB and Quality Watch in 2010 as commissioned by the Polish Agency for Enterprise Development (PARP), Warszawa 2010. The quantitative research was performed on two groups of respondents: regular employees of SMEs $(n-1,200)$ and 600 members of the SME top manage- 
ment. Due to the size limits of this paper, only the research results concerning the top management are shown. The quantitative research was carried out using questionnaire-based paper and pencil interviews. The quantitative research on the top management was performed on a representative sample of 600 Polish SMEs, whereas random-quota sampling was used for the purposes of representing the enterprise population. The enterprises were sampled randomly subject to stratification in respect of: the size of the enterprise, its age, the industry in which it operates - its chief activity profile (according to the sections of the Polish Classification of Activity (PKD) 2004). According to our assumptions, the examined sample met the following criteria: randomly sampled from a registry of active enterprises, representative of the SME sector, the size of the sample allows for conclusions to be drawn in respect of the entire SME sector and its main industries.

In the research, the most numerous group was that of micro-enterprises -300 entities, accounting for $50 \%$ of the whole sample. Small enterprises were populously represented, as well - by 250 entities, which accounted for $41.7 \%$ of the whole sample. The rest of the research sample was made up by medium enterprises - 50 entities, accounting for $8.3 \%$ of the whole sample.

In this research, the largest group was that of the trade and repairs section businesses - 196 entities, which accounted for $32.7 \%$ of the sample; the industry section was represented by 78 entities, or $13 \%$; construction - 73 entities, or 12.2\%; support to businesses (including services for businesses), real estate - 72 entities, or $12 \%$; and education - 72 entities, or $12 \%$. The share of the remaining sections in the examined sample did not exceed $4.5 \%$ per section. The share of particular PKD sections in the examined sample was balanced in respect of the size of the enterprises studied (PARP Report, 2010).

The purpose of the studies presented in this paper was to determine two correlations: first of all, the dependency between the SME's competitive position and the top management's qualifications, and second of all the dependency between the SME's competitive position and the top management's competences. The first dependency was analyzed by studying the level and profile of the top management's education divided into groups of enterprises of various competitive positions. The second dependency was analyzed by studying the level of the top management's competence divided into groups of enterprises of various competitive positions.

The relative role of the top management's qualifications in shaping the competitiveness of the SMEs studied can be determined by analyzing the top management's educational level and profile, according to groups of enterprises characterized by different competitive positions. It can be expected that the educational background will have a causal impact on the competitive position. An analysis was performed of the dependency between the competitive position and the top management's qualifications, dividing the enterprises into two groups: one of companies with the top management composed of persons with a degree, and another one of companies in which none of the top management members had a degree (Chart 1). 


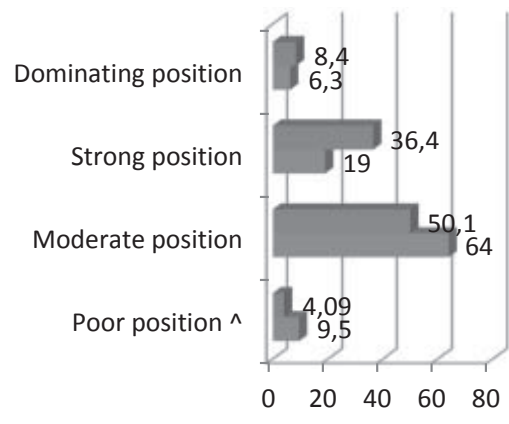

There are graduates of higher education institutions (\%)

A lack of graduates of higher education institutions (\%)

* statistical significance $\mathrm{p}<0,05$

$\wedge$ note: small numbers

Chart 1. Competitive position according to the top management's educational background Source: Study based on Research Report (PARP 2010, p. 81) "The educational background of employees and the enterprises' competitive position”; research conducted by WYG group's PSDB and Quality Watch in 2010 as commissioned by the Polish Agency for Enterprise Development (PARP), Warszawa: PARP.

Among the enterprises in which the top management members had a degree, $8.4 \%$ occupied a dominating position, while a dominating position was held by far fewer among those controlled by managers without a degree $-6.3 \%$. However, a significant difference was observed where the competitive position was strong. As many as over $36 \%$ of enterprises managed by better educated managers held this advantageous position in the market, while among enterprises managed by less educated managers only $19 \%$ held the same position. Opposite proportions of the share of those two enterprise groups can be observed when analyzing the poor competitive position. Here, there were over twice as many companies managed by a less educated top management. This gave reasons for the conclusion that the managers' qualifications had a strong impact on the competitiveness of the enterprises studied. The level of the SME top management's education had a larger effect on the competitiveness of these enterprises than the formal educational background of their regular employees.

As a consequence of the foregoing statement, there was a need for a further analysis of the impact of the type of the top management's educational background on the competitiveness of the enterprises. In order to do this, it was necessary to carry out an additional classification of companies according to the dominating type of their managers' educational background. Four groups of enterprises were distinguished:

- the first group - 50\% and more of the top management were persons with a degree in technology (184 entities were allocated to this group, i.e. $30.7 \%$ of the sample)

- the second group $-50 \%$ and more of the top management were persons with a degree in economics (174 entities, i.e. $29 \%$ of the sample),

- the third group - 50\% and more of the top management were persons with a degree in other fields: exact, natural, social and legal sciences, or other (172 entities, i.e. $28.7 \%$ of the sample),

- the fourth group - other enterprises with a relatively balanced top management composition in respect of the type of their educational background (none of the types exceeds 50\%) (70 entities, i.e. $11.7 \%$ of the sample).

The analysis of the correlation between the enterprises' competitive position and the dominating type of the top management's educational background is shown in Chart 2. 


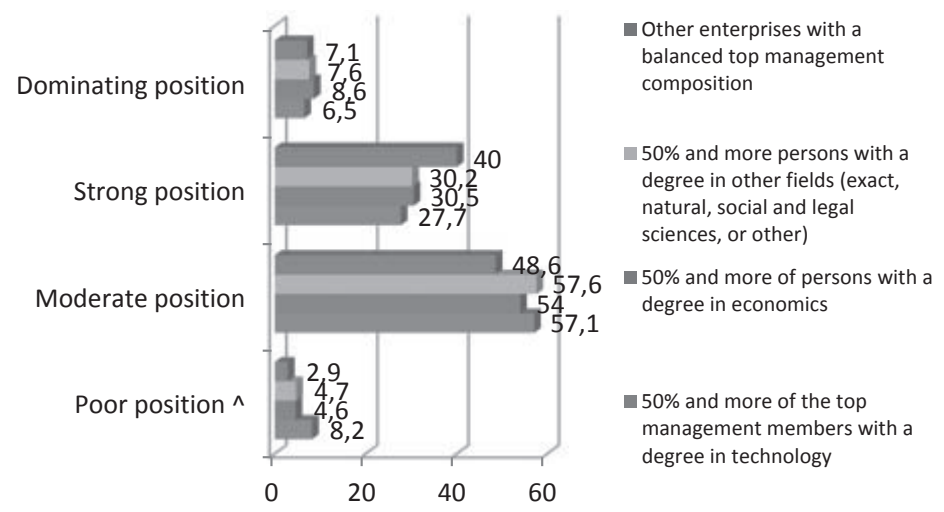

$\wedge$ note: small numbers

Chart 2. Competitive position according to the top management's educational profile. Source: Study based on Research Report (PARP 2010, p. 82).

In the case of the dominating competitive position, a small advantage was observed in favor of those enterprises whose top management was dominated by persons with a degree in economics. Other groups of enterprises occupied a slightly less privileged position in the market, whereas it was companies with the top management dominated by persons with degrees in technology that were the least represented in this category. However, the most characteristic result came up while analyzing the share of particular types of enterprises whose market position was strong. Here, much better results were achieved by enterprises with a balanced composition of the top management. As many as $40 \%$ of enterprises from this group occupied a strong position. Moreover, over $7 \%$ of them held a dominating position. As it turns out, actually every second enterprise run by a balanced top management demonstrated high competitiveness. As for the poor position, the most represented group of enterprises was that of companies run by managers with degrees in technology.

The particularly good results achieved by enterprises run by management teams with a diversified educational background might have come as a surprise until recently. Traditionally, it appears that the optimal educational background would be a degree in economics, and that due to the fact of the economists' knowledge of the market and management. Also, degrees in technology were appreciated as strongly linked to the technologies used in small enterprises. However, this researched showed that due to the new challenges faced by companies, such as the knowledge economy, no type of education is sufficient for the purposes of running a business. Probably, in those of the enterprises studied which employed top managers with a diversified educational background, their educational composition had to a large extent been formed randomly.

Nevertheless, the conclusion that a diversified educational background of the top management is especially effective should suggest that it is necessary for contemporary enterprises to form multidisciplinary management teams. Naturally, in the case of micro enterprises this should be understood as a need to engage, permanently or periodically, with people of an educational profile different to that of the owner-manager when it comes to making managerial decisions. Combining knowledge within teams of a diversified educational background is the most effective method for responding to the modern competitive challenges. 


\section{TOP MANAGEMENT'S COMPETENCE AND THE ENTERPRISES' COMPETITIVE POSITION}

In this research, 39 competences of the top management were analyzed as divided into six categories: business, enterprise-related, personal, cognitive, social and managerial competences. The level of the top managers' competence was assessed on a scale of 1 (no competence) to 10 (excellent competence).

As regards the top managers' business competences (Chart 3), it was found that their level varied significantly among enterprises of different competitive positions. Among them, two competences stood out as the most widely appreciated by managers, namely substantial knowledge stemming from experience and the knowledge of the industry.

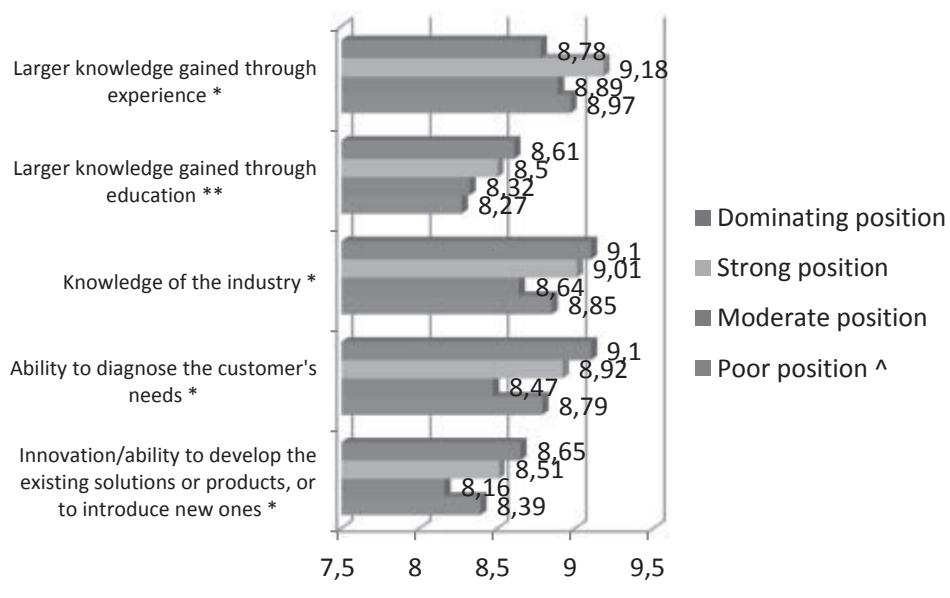

\footnotetext{
* statistical significance $\mathrm{p}<0,05$

** statistical trend $0.05<\mathrm{p}<0.10$

$\wedge$ note: small numbers
}

Chart 3. Competitive position and the top management's business competences.

Source: Study based on Research Report (PARP 2010, p. 91).

Also in the case of other business competences assessed - i.e. the ability to diagnose the customer's needs, and the innovation in developing the existing solutions or products, or introducing new ones - the differences turned out to be significant. However, in the case of such business competences as substantial knowledge stemming from education, an observable statistical trend was noted.

In general, certain differences were observed in favor of enterprises holding dominating and strong positions, although these differences were probably smaller than one would have expected. On the competence assessment scale of 1 to 10 , these differences amounted to up to 0.4 points. Moreover, it is difficult to talk of a regularity with which the assessment of individual competences increased in enterprises enjoying a higher potential. Supposedly, these competences should be treated as necessary for the managers, but causing no differentiation of the competitiveness of the enterprises that they managed.

As it comes to cognitive competences, significant differences occur in respect of all of the traits (Chart 4). A considerably higher level of the top managers' competence is observed in enterprises holding a dominating position with regard to analytical thinking skills, an ability to learn fast and to develop con- 
tinuously, responding rapidly to changing tasks and their completion circumstances, openness to changes and an ability to solve problems quickly.

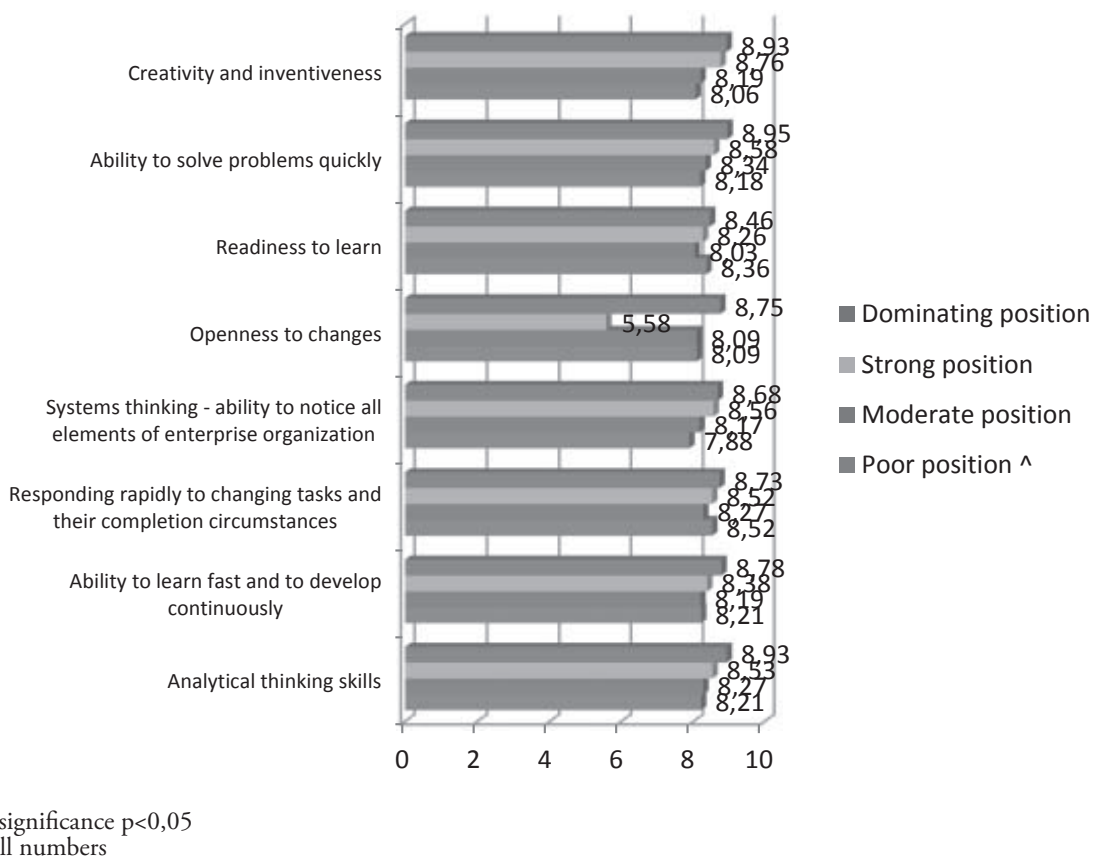

* statistical significance $\mathrm{p}<0,05$

$\wedge$ note: small numbers

Chart 4. Competitive position and the top management's cognitive competences* ${ }^{*}$. Source: Study based on Research Report (PARP 2010, p. 93).

Principally, the cognitive competence advantage observed in managers from the most competitive enterprises seems to point to the particular and critical role of those competences which allowed them to quickly adapt to changing circumstances. The analysis shows that the enterprise's competitive position was largely contingent on its top managers' adaptation ability and flexibility.

When studying the top managers' competences one could expect that potentially the largest impact on competitiveness will be exerted by those defined as managerial competences. Indeed, the analysis results showed in this case that relatively larger differences in competence levels were between companies of different competitive positions. An analysis of managerial competences is shown in Chart 5. 


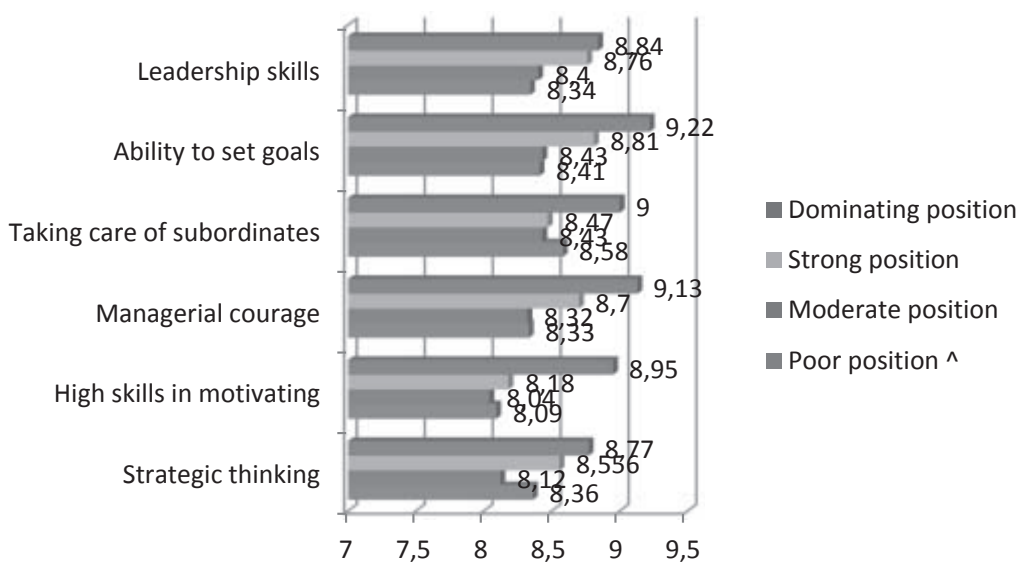

* statistical significance $\mathrm{p}<0,05$

$\wedge$ note: small numbers

Chart 5. Competitive position and the top management's managerial competences * .

Source: Study based on Research Report (PARP 2010, p. 94).

The advantage of enterprises with dominating levels of managerial competences was observed in all cases. It was particularly clear with regard to high skills in motivating, managerial courage, taking care of subordinates and an ability to set goals. A high level of competences in respect of leadership skills and strategic thinking was also found in companies holding strong competitive positions. The entirety of the analysis of the managerial competences confirmed their significant impact on the competitiveness of enterprises.

\section{CONCLUSIONS}

The main measure of the ultimate competitiveness, namely the competitive position of the enterprise, is its competitive potential as composed of tangible and intangible resources. It appears that SME managers still attach the most importance to the quality of the tangible resources as an element of the competitive potential. Small enterprises, which find it hard to maintain a high level of tangible resources, should in the first place, similarly to most of their competitors, shape their competitiveness on the basis of intangible resources, mainly those related to the qualifications and competence of their staff, particularly their top management.

The high level of competitiveness of the enterprises studied was mostly a result of the manager's educational background and competence. Their high level of qualifications contributed to the enterprises' adaptability, which was necessary under the conditions of a volatile and unfavorable environment. Enterprises employing managers with degrees from higher education institutions were more open not only to new technological solutions, but also to new organizational solutions and cooperation with other entities for the purposes of developing products and services.

The advantage of companies employing better educated managers is not only limited to the competitive potential components that can be defined as elements of knowledge and competence, but also takes into account their advantage in respect of the quality of machinery and equipment, the modernity of the technologies used, the distribution network, the financial resources and the enterprise's brand or image. 
Apart from the level of the managers' educational background, the types of their degrees played a role here, as well. Basically, those enterprises were more successful in the market which employed a balanced composition of the management team, not dominated by any of the educational profiles: technical, economic or any other. Of the top managers' competences, of a crucial role were managerial and cognitive competences connected with an ability to operate under volatile conditions.

The substantial importance of the top management's qualifications and competence as a factor of the enterprises' competitiveness which arises from this research shows that there is a need for particular attention to be given to the human capital within the organization's system of competitive potential resources. Also, the insufficient awareness of the necessity of and benefits from raising qualifications and competence under the circumstances of the knowledge economy is to be seen as vital.

Therefore, as it arises from the aforementioned PARP Report of 2010, recommendations should be made as divided into the following areas aimed to:

- educate the top management members in order to equip them with missing competences,

- raise the top managers' awareness with regard to the importance of intangible resources for the shaping of the enterprise's competitive position, the importance of the employees' qualifications and competence, and the importance of in-house education,

- increase employee adaptability through: increasing their opportunities in the labor market as a result of their raising qualifications, increasing responsibility for self-education, increase enterprise adaptability by supporting innovation and competition.

\section{REFERENCES:}

Boyatzis R. E. (1982), The Competent Manager: A Model for Effective Performance, New York: John Wiley\&Sons.

Buckley P., Pass C., Prescott K. (1988), Measures of International Competitiveness: a Critical Survey, Journal of Marketing Management. Vol. 4, No. 2.

Day G.S. (1997), Maintaining Competitive Edge: Creating and Sustaining Advantages in Dynamic Competitive Environments, w: Day G.S., Reibstein D.J., Gunter R.E. (ed.) Wharton on Dynamic Competitive Strategy, New York: John Wiley \& Sons, Inc.

Delamare Le Deist, Winterton J. (2005), What is competence? Human Resources Development International. T. 8.

Filipowicz G. (2004), Zarzadzanie kompetencjami zawodowymi, Warszawa: PWE.

Flak O., Głód G. (2009), Konkurencyjność przedsiębiorstwa. Pojęcia, definicje, modele, cz. 1., Katowice: Wyd. AE w Katowicach.

Gierszewska G., Romanowska M. (2009), Analiza strategiczna przedsiębiorstwa, Warszawa: PWE.

Godziszewski B. (2001), Zasobowe uwarunkowania strategii przedsiębiorstwa, Toruń: Wyd. UMK.

Gorynia M. (2000), Zachowania przedsiębiorstw w okresie transformacji. Mikroekonomia przejścia, Poznań: Wyd. AE w Poznaniu.

Gorynia M., Łaźniewska E. (2010) (red.), Kompendium wiedzy o konkurencyjności, Warszawa: PWN.

Hax A.C., Majluf M.N. (1990), The Use of the IndustryAttractiveness- Business Strength Matrix in Strategic Planning, w: R.G. Dyson (ed.), Strategic Planning: Models and Analytical Techniques, Chichester: John Wiley \& Sons Inc.

http://www.kwalifikacje.praca.gov.pl/ data pobrania 02.04.2014.

http://www.mpips.gov.pl/praca/bazy-danych-mpips-dla-potrzeb-edukacji-i-pracy/modulowe-programy-szkolen-zawodowych, data pobrania 02.04.2014.

https://www.biurokarier.umk.pl/kwalifikacje-a-kompetencje, data pobrania 02.04.2014.

Kay J. (1996), Podstawy sukcesu firmy, Warszawa: PWE. 
Low J., Kalafut P.C. (2002), Niematerialna wartość firmy, Kraków: Oficyna Ekonomiczna.

Lyons P. (2007), A Leadership Development Model to Improve Organizational Competitiveness, w: Advances in Competitiveness Research, Vol. 15.

McClelland D.C. (1973), Testing for competence rather than for 'intelligence', American Psychologist, No 1.

Penrose E.T. (1959), The Theory of the Growth of the Firm, New York: John Wiley\&Sons.

Pierścionek Z. ( 2007), Strategie konkurencji i rozwoju przedsiębiorstwa, Warszawa: PWN.

Pocztowski A. (2001), Wokót pojęcia kompetencji i ich znaczenia w zarządzaniu zasobami ludzkimi, w: Urbaniak B., (red.), Gospodarowanie praca, Łódź: Wydawnictwo Uniwersytetu Łódzkiego.

Porter M. E. (2006 a), Przewaga konkurencyjna. Osiaganie i utrzymywanie lepszych wyników, Gliwice: Wyd. Helion.

Porter M. E. (2006 b), Strategia konkurencji. Metody analizy sektorów i konkurentów, Warszawa: MT Biznes.

Raven J. (1984), Competence in Modern Society: Its Identification, Development and Release, Oxford: Psychologists Press. Sienkiewicz Ł., Gruza M. (2009), Badanie kwalifikacji i kompetencji oczekiwanych przez pracodawców od absolwentów ksztatcenia zawodowego, Warszawa: Wyd. Studio Magic.

Spencer L.M., Spencer S.M. (1993), Competence at work: Models for Superior Performance, New York: John Wiley \& Sons Inc.

Stankiewicz M.J. (2005), Konkurencyjność przedsiębiorstwa. Budowanie konkurencyjności przedsiębiorstwa w warunkach globalizacji, Toruń: Wyd. Dom Organizatora.

STRATEGOR (2001), Zarządzanie firmą: strategie, struktury, decyzje, tożsamość, Warszawa: PWE.

Taggart J. i J., International Competitiveness and the Single Currency, Business Strategy Review, Vol. 10, Issue 2.

Woodruffe Ch. (2003), Ośrodki oceny i rozwoju. Narzędzia analizy i doskonalenia kompetencji pracowników, Oficyna Ekonomiczna, Kraków: Dom Wydawniczy ABC. 